\title{
FORMULASI GEL HAND SANITIZER ANTIBAKTERI KOMBINASI EKSTRAK RUMPUT LAUT Eucheuma spinosum DAN Eucheuma cotonii ASAL KEPULAUAN WAKATOBI SULAWESI TENGGARA
}

\author{
Formulation of Antibacterial Hand Sanitizer Gel of Combination of Eucheuma spinosum and Eucheuma cotonii Seaweed \\ Extract from Wakatobi Island Southeast Celebes \\ Nur Illiyyin Akib ${ }^{*}$, Inten Widuri Wulandari1, Suryani1, Hanari2 \\ 1Fakultas Farmasi, Universitas Halu Oleo, Kendari, Sulawesi Tenggara, Indonesia \\ ${ }_{2}$ Dinas Kesehatan Provinsi Sulawesi Tenggara, Indonesia \\ *Email korespondensi: nurilliyyinakib@gmail.com (Telp: +6285399937282) \\ Diterima: 30 September/ Disetujui 7 Oktober 2019
}

Cara sitasi: Akib NI, Wulandari IW, Suryani, Hanari. 2019. Formulasi gel hand sanitizer antibakteri kombinasi ekstrak rumput laut Eucheuma spinosum dan Eucheuma cottonii asal kepulauan Wakatobi Sulawesi. Jurnal Fish Protech. 2(2):180-188.

\section{ABSTRACT}

Wakatobi Islands is the largest seaweed production center in Southeast Sulawesi. Seaweed needs to be developed into of high economic value products. An antibacterial hand sanitizer gel formulation was carried out containing a combination of Eucheuma spinosum and Eucheuma cottonii seaweed extract. The aims of the study are accepting a combination of hand sanitizer gel formulation which have antibacterial activity. Seaweed was extracted by maceration method using methanol as a solvent. The combination of extracts at concentrations of $1 \%, 2 \%, 4 \%$, and $8 \%$ with a ratio of 1: 1 determined the MIC and MBC against Staphylocccus aureus and Escherichia coli using dilution method. The combination of extracts that can kill bacteria is formulated into a hand sanitizer gel preparation using a carbopol as base of gel by mechanical dispersion method. Gel is characterized by organoleptics and pH. Antibacterial activity of gel against the bacteria $S$. aureus and E. coli using the dilution method. The results obtained by the MIC value for S. aureus bacteria is $2 \%$ and for $E$. coli bacteria is $4 \%$. MBC value of the combination of extracts against $S$. aureus and $E$. coli bacteria was $4 \%$. Gel preparations were obtained in the form of semisolid, green, clear, green tea scent, and pH 6.3 and 5.7. It was concluded that hand sanitzer gel with a concentration of $4 \%$ had bactericidal activity againts $E$. coli and S. aureus.

Keywords: Antibacterial, hand sanitizer gel, seaweed, Wakatobi.

\section{ABSTRAK}

Kepulauan Wakatobi merupakan sentra penghasil rumput laut terbesar di Sulawesi Tenggara. Rumput laut perlu dikembangkan menjadi produk yang bernilai ekonomi tinggi. Telah dilakukan formulasi sediaan gel antibakteri hand sanitizer yang mengandung kombinasi ekstrak rumput laut Eucheuma spinosum dan Eucheuma cottonii. Penelitian ini bertujuan memperoleh sediaan kombinasi gel hand sanitizer yang memiliki aktivitas antibakteri. Rumput laut diekstraksi dengan metode maserasi menggunakan pelarut metanol. Kombinasi ekstrak pada konsentrasi 1\%, 2\%, 4\%, dan 8\% dengan perbandingan 1:1 ditentukan KHM dan KBM-nya terhadap bakteri Staphylocccus aureus dan Escherichia coli menggunakan metode dilusi. Kombinasi ekstrak yang dapat membunuh bakteri selanjutnya diformulasi menjadi sediaan gel hand sanitizer dengan basis karbopol menggunakan metode dispersi mekanik. Sediaan gel dikarakterisasi organoleptik dan pH-nya. Serta diuji aktivitasnya terhadap bakteri $S$. aureus dan $E$. coli menggunakan metode dilusi. Diperoleh hasil nilai KHM terhadap bakteri $S$. aureus adalah $2 \%$ dan terhadap bakteri $E$. coli adalah $4 \%$. Nilai KBM kombinasi ekstrak terhadap bakteri S. aureus dan E. coli adalah 4\%. Sediaan gel diperoleh dengan bentuk semipadat, warna hijau, bening, beraroma pewangi green tea, serta pH 6,3 dan 5,7. Disimpulkan bahwa sediaan gel hand sanitizer dengan konsentrasi ekstrak 4\% memiliki aktivitas bakterisidal atau dapat membunuh bakteri E. coli dan S. aureus.

Kata kunci: Antibakteri, Gel hand sanitizer, Rumput laut, Wakatobi. 


\section{PENDAHULUAN}

Penyakit infeksi merupakan salah satu penyebab tingginya angka kesakitan dan kematian yaitu termasuk dalam sepuluh besar penyakit paling mematikan di dunia (WHO, 2012). Penyakit infeksi disebabkan oleh bakteri terutama Escherichia coli dan Staphylococcus aureus. Bakteri- tersebut menginfeksi dan menyebabkan penularan pada manusia melalui kulit terutama pada telapak tangan (Shu, 2013). Pencegahan infeksi bakteri dapat dilakukan dengan menjaga kebersihan telapak tangan.

Cara paling sederhana untuk menjaga kebersihan tangan adalah mencuci tangan menggunakan sabun dan air. Namun seiring bertambahnya kesibukan masyarakat terutama di perkotaan maka tercipta produk yang cepat dan praktis yaitu pencuci tangan tanpa air yang dikenal dengan hand sanitizer.

Hand sanitizer merupakan sediaan berbentuk gel yang mengandung zat aktif antibakteri alami ataupun sintetik (Shu, 2013). Saat ini telah beredar produkproduk hand sanitizer dengan bahan aktif kimia sintetik misalnya triklosan. Namun triklosan berbahaya jika digunakan berlebihan dan jangka waktu lama karena dapat menyebabkan resistensi bakteri, pencemaran lingkungan, dan memicu alergi. Akumulasi triklosan dalam tubuh dapat mengakibatkan kelumpuhan, kemandulan, lemahnya fungsi tubuh, pendarahan otak, penurunan fungsi kelamin, masalah jantung bahkan hingga koma (Kristiyana, 2013). Oleh karena itu, diperlukan alternatif yaitu bahan aktif yang berasal dari bahan alami (Siregar dkk., 2012).

Salah satu tumbuhan yang memiliki aktivitas antibakteri adalah rumput laut. Spesies Eucheuma spinosum dan Eucheuma cottoni paling banyak ditemukan di Indonesia khususnya Sulawesi Tenggara (Suparmi dan Achmad, 2009; Arsal, 2014). Penelitian sebelumnya menunjukkan bahwa $E$. spinosum dan $E$. cottonii mengandung flavonoid, triterpenoid, steroid, dan alkaloid yang memiliki aktivitas terhadap bakteri $S$. aureus dan E. coli (Siregar, dkk., 2012; Mardiyah dkk., 2014; Andriani dkk., 2015).
Kabupaten Wakatobi, Provinsi Sulawesi Tenggara merupakan kawasan taman nasional dengan luas $1.390 .000 \mathrm{Ha}$, terdiri atas $97 \%$ lautan dan $3 \%$ daratan. Masyarakat Wakatobi banyak memanfaatkan sumber daya laut termasuk untuk pengobatan yaitu rumput laut E.spinosum dan $E$. cottonii.

Penelitian oleh Al-Haj dkk. (2009) menunjukkan bahwa ekstrak metanol $E$. spinosum memiliki aktivitas antibakteri terhadap bakteri $S$. aureus dengan Konsentrasi Hambat Minimum (KHM) 2\% dan Konsentrasi Bunuh Minimum (KBM) 4\%. Hasil penelitian lainnya yang dilakukan oleh Sartika dkk. (2013) menunjukkan bahwa ekstrak metanol rumput laut $E$. cottonii memiliki aktivitas antibakteri terhadap bakteri E. coli dan S. aureus dengan KHM 1\%.

Berdasarkan latar belakang tersebut peneliti mengembangkan suatu produk hand sanitizer dengan senyawa bioaktif antibakteri yang terkandung dalam rumput laut $E$. spinosum dan $E$. cottonii. Penelitian ini bertujuan menghasilkan sediaan gel hand sanitizer dengan bahan aktif alami yang efektif terhadap bakteri E. coli dan S. aureus penyebab infeksi.

\section{BAHAN DAN METODE}

\section{Bahan}

Rumput laut $E$. spinosum, rumput laut $E$. cottonii, metanol, karbopol (Pharmacos $₫$ ), trietanolamin, metil paraben, propilen glikol, pewangi green tea, pewarna fast green, metanol, air suling, selampai kertas, kasa steril, kapas steril, kertas saring, Nutrient Agar (NA) (Oxoid®), Nutrient Broth (NB) (Himedia®), $\mathrm{NaCl} 0,9 \%$ (Widatra®), $\mathrm{H}_{2} \mathrm{SO}_{4}$ (Mallinckrodt $\left.{ }_{\circledast}\right), \mathrm{BaCl}_{2}$ (Merck®), triklosan (Merck®), dimetil sulfoksida (DMSO) (Merck®), sediaan gel hand sanitizer merek $\mathrm{Y}$, Escherichia coli ATCC 35218, dan Staphylococcus aureus ATCC 25923. 


\section{Tahapan Penelitian}

\section{Penyiapan ekstrak}

Sampel E. cottonii dan E. spinosum diperoleh di Kelurahan Ambeua, Kecamatan Kaledupa, Kabupaten Wakatobi, Provinsi Sulawesi Tenggara. Sampel masing-masing $5 \mathrm{~kg}$ disortasi basah, dicuci, dirajang, dikeringkan $(40 \circ \mathrm{C})$, disortasi kering, dan dicacah hingga diperoleh serbuk kering.

Serbuk kering $300 \mathrm{~g}$ dimaserasi dengan $900 \mathrm{~mL}$ pelarut metanol selama 24 jam sehingga diperoleh filtrat. Maserasi diulangi hingga filtrat bening. Sisa pelarut pada filtrat diuapkan menggunakan rotary evaporator $(40 \circ \mathrm{C})$ dan waterbath $(40 \circ \mathrm{C})$ hingga diperoleh ekstrak kental. Dihitung rendemen ekstrak (Hanapi dkk., 2013).

\section{Pengujian aktivitas antibakteri ekstrak}

1. Sterilisasi alat: menggunakan oven ( \pm 2 jam, 170 。C) atau autoklaf (15 menit, 121。C, $15 \mathrm{psi})$ (Hasriani dkk., 2013).

2. Pembuatan media NA: sebanyak $5,7 \mathrm{~g}$ media NA dilarutkan dalam $200 \mathrm{~mL}$ air suling dan dipanaskan hingga larut. Larutan media dituangkan dalam tabung masing-masing $3 \mathrm{~mL}$ dan disterilkan menggunakan autoklaf. Tabung NA dimiringkan segera setelah dikeluarkan dari autoklaf.

3. Pembuatan media NB: sebanyak 2,6 g media NB dilarutkan dalam $200 \mathrm{~mL}$ air suling dan dipanaskan hingga larut. Larutan media dituangkan dalam tabung masing-masing $5 \mathrm{ml}$, ditutup dengan kapas, dan disterilkan menggunakan autoklaf.

4. Peremajaan bakteri: sebanyak 1 jarum ose stok bakteri $S$. aureus dan $E$. coli dinokulasi ke dalam media NA miring lalu diinkubasi (24 jam, 37.C) (Paju dkk., 2013).
5. Pembuatan larutan McFarland Standar 0,5: $9,95 \mathrm{~mL} \mathrm{H}_{2} \mathrm{SO}_{4} \quad 1 \%$ dan $0,05 \mathrm{~mL} \mathrm{BaCl} 21 \%$ yang dikocok membentuk larutan keruh. Larutan tersebut setara dengan kepadatan bakteri $1,5 \times 108 \mathrm{CFU} / \mathrm{mL}$ atau $150 \times 106$ $\mathrm{CFU} / \mathrm{mL}$

6. Pembuatan suspensi bakteri: sebanyak 1 ose hasil peremajaan bakteri dimasukkan ke dalam $10 \mathrm{~mL} \mathrm{NaCl} \mathrm{0,9 \% ,} \mathrm{dihomogenkan}$ menggunakan vortex, dihitung kekeruhan bakteri sesuai standar Mc Farland 0,5.

7. Pembuatan larutan uji kombinasi ekstrak (1:1): variasi konsentrasi $1 \%, 2 \%, 4 \%$, dan $8 \%$ dibuat dengan melarutkan ekstrak ke dalam DMSO. Larutan kontrol positif adalah triklosan $1 \%$ dalam pelarut DMSO.

8. Penentuan Konsentrasi Hambat Minimum (KHM) dilakukan dengan metode dilusi cair: Setiap tabung diisi dengan $4,8 \mathrm{~mL}$ media NB dan $0,1 \mathrm{~mL}$ suspensi bakteri. Tabung uji (A, $B$, $\mathrm{C}$, dan $\mathrm{D}$ ) ditambahkan 0,1 mL larutan ekstrak masing-masing variasi konsentrasi. Tabung kontrol positif $\left(\mathrm{K}_{1}\right)$ ditambahkan $0,1 \mathrm{~mL}$ triklosan 1\%. Tabung kontrol pelarut $\left(\mathrm{K}_{2}\right)$ ditambahkan 0,1 mL DMSO. Tabung kontrol negatif (K $\left.\mathrm{K}_{3}\right)$ tanpa penambahan. Tabung kontrol normal $\left(\mathrm{K}_{4}\right)$ hanya berisi media NB. Seluruh tabung diinkubasi (24 jam, 37。C), kemudian diamati pertumbuhan bakteri berupa kekeruhan. KHM adalah konsentrasi ekstrak terendah yang tampak jernih.

9. Penentuan Konsentrasi Bunuh Minimun (KBM) dilakukan dengan metode dilusi padat. Masingmasing isi tabung digoreskan di atas media NA padat, diinkubasi (24 jam, 37。C), dan diamati pertumbuhan bakteri. KHM adalah konsentrasi ekstrak terendah yang tidak ditumbuhi bakteri. 
Tabel 1. Formula 50 gram gel

\begin{tabular}{cccc}
\hline No & Bahan & Konsentrasi (\%) & Fungsi \\
\hline 1 & Kombinasi ekstrak & 4 & Zat aktif \\
2 & Karbopol & 0,5 & Pembentuk gel \\
3 & Trietanolamin & 5 tetes & Penetral \\
4 & Propilen glikol & 15 & Humektan \\
5 & Metil paraben & 0,2 & Pengawet \\
6 & Parfum green tea & 2 tetes & Pengaroma \\
7 & Pewarna fast green & 1 tetes & Pewarna \\
8 & Alkohol & 15 & Pembantu penguapan \\
9 & Air suling & 65,3 & Pelarut \\
\hline
\end{tabular}

Karbopol didispersikan dalam $\mathrm{mL}$ air suling dan diamkan 24 jam, ditambahkan 2 tetes trietanolamin hingga terbentuk massa A. Metil paraben, ekstrak $E$. spinosum, dan ekstrak $E$. cottonii dilarutkan dalam propilen glikol dan alkohol hingga terbentuk massa B. Selanjutnya massa B ditambahkan sedikit demi sedikit ke dalam massa $A$, diaduk hingga homogen, dan ditambahkan sisa air hingga terbentuk massa $C$. Pewarna fast green dilarutkan dalam alkohol, ditambahkan ke dalam massa $\mathrm{C}$ hingga homogen, lalu ditambahkan parfum green tea.

\section{Karakterisasi sediaan gel}

Uji organoleptik berupa pengamatan tekstur, warna, dan bau sediaan (Ansel, 1989). Uji pH dilakukan dengan alat $\mathrm{pH}$-meter yang dicelupkan ke dalam 1 gram gel yang dilarutkan dalam $10 \mathrm{ml}$ air suling (Setyaningrum, 2010).

\section{Pengujian aktivitas antibakteri sediaan gel}

Pengujian menggunakan metode dilusi cair terhadap bakteri $S$. aureus dan $E$. coli dilanjutkan dengan penggoresan pada media untuk memastikan efek bakterisidal sediaan. Gel 5 gram ditambahkan alkohol hingga volume menjadi $5 \mathrm{ml}$, dilakukan pula terhadap kontrol negatif (basis) dan kontrol positif (merek Y). Disiapkan 10 tabung yang masing-masing berisi $4,8 \mathrm{ml}$ media NB.

\begin{tabular}{lll}
\begin{tabular}{l} 
Tabel 2. Perlakuan \\
\hline Tabung
\end{tabular} & $\begin{array}{l}\text { Suspensi } \\
\text { bakteri }(\mathbf{0 , 1} \mathbf{m l})\end{array}$ & $\begin{array}{l}\text { Suspensi gel } \\
(\mathbf{0}, 1 \mathrm{ml})\end{array}$ \\
\hline $\mathrm{A}$ & S. aureus & Sampel uji \\
$\mathrm{B}$ & E. coli & Sampel uji \\
$\mathrm{C}$ & S. aureus & Kontrol negatif \\
$\mathrm{D}$ & E. coli & Kontrol negatif \\
$\mathrm{K}_{1}$ & S. aureus & Kontrol positif \\
$\mathrm{K}_{2}$ & E. coli & Kontrol positif \\
$\mathrm{K}_{3}$ & S. aureus & - \\
$\mathrm{K}_{4}$ & E. coli & - \\
\hline
\end{tabular}

Seluruh tabung diinkubasi (24 jam, 37oC), kemudian diamati pertumbuhan bakteri berupa kekeruhan. Semua tabung diinkubasi selama 1 × 24 jam pada suhu $37 . C$. Lalu masing-masing isi tabung digoreskan di atas media NA padat dan diinkubasi (24 jam, $370 \mathrm{C}$ ), kemudian diamati pertumbuhan bakteri.

\section{HASIL DAN PEMBAHASAN \\ Penyiapan ekstrak}

Ekstraksi dilakukan dengan metode maserasi karena proses pengerjaannya sederhana dan dilakukan pada suhu ruang sehingga dapat menghindari kerusakan metabolit dalam sampel yang tidak stabil terhadap pemanasan (Putra dkk., 2014). Pelarut yang digunakan adalah metanol karena dapat melarutkan metabolit yang bersifat polar dan nonpolar (Thompson, 1985). Metanol merupakan pelarut terbaik untuk ekstraksi metabolit dari rumput laut yaitu flavonoid, triterpenoid, steroid, dan alkaloid yang berperan sebagai antibakteri (Andriani dkk., 2015). 
Tabel 3. Perolehan ekstrak

\begin{tabular}{lccc}
\hline Rumput laut & Sampel kering (g) & ekstrak kental (g) & Rendemen ekstrak (\%) \\
\hline E. spinosum & 300 & 8,7 & 2,90 \\
E. cotonii & 300 & 7,7 & 2,57 \\
\hline
\end{tabular}

Maserasi rumput laut dengan metanol menghasilkan berat ekstrak yang lebih banyak dibandingkan pelarut konvensional lainnya. Selain itu metanol aman digunakan untuk formulasi sediaan topikal. (Siregar dkk., 2012)

\section{Pengujian aktivitas antibakteri ekstrak}

Pengujian aktivitas ekstrak bertujuan memperoleh KHM dan KBM yang menjadi dasar penentuan konsentrasi ekstrak dalam formulasi gel hand sanitizer. Bakteri uji yang digunakan adalah $S$. aureus (Gram positif) dan E. coli (Gram negatif). Kedua bakteri tersebut merupakan flora normal kulit manusia dan penyebab infeksi paling sering ( Shu, 2013).

NA dan NB digunakan sebagai media karena cocok untuk pertumbuhan bakteri uji. DMSO digunakan sebagai pelarut karena kombinasi ekstrak E. spinosum dan E. cottonii tidak larut dalam air suling. DMSO dapat melarutkan hampir semua senyawa baik polar maupun nonpolar. DMSO tidak memiliki aktivitas bakterisidal sehingga tidak mengganggu hasil pengamatan pengujian aktivitas antibakteri.

Larutan triklosan $1 \%$ digunakan sebagai kontrol positif bersifat bakterisidal dan memiliki efek antibakteri spektrum luas sehingga efektif digunakan terhadap bakteri uji. Penggunaan triklosan juga berdasarkan kontrol positif sediaan gel hand sanitizer merek $Y$ yang digunakan pada uji antibakteri sediaan gel.

Kontrol positif bertujuan mengetahui apakah sampel uji memiliki aktivitas antibakteri yang sama dengan triklosan atau tidak. Kontrol pelarut bertujuan mengetahui apakah DMSO memiliki aktivitas antibakteri atau tidak. Kontrol negatif bertujuan mengetahui apakah bakteri dapat tumbuh dengan baik pada media, parameter kekeruhan pada uji KHM, dan parameter pertumbuhan bakteri pada uji KBM. Kontrol normal merupakan parameter keberhasilan sterilisasi, pertumbuhan bakteri, dan adanya kontaminan.

Variasi konsentrasi ekstrak 1\%, 2\%, 4\%, dan 8\% mengacu pada KBM ekstrak E.spinosum adalah 4\% (Al-Haj, dkk., 2009) bahwa KHM ekstrak E. cottonii adalah 1\% (Sartika, dkk., 2013).

Penentuan KHM menggunakan metode dilusi cair karena dapat diketahui jumlah sel bakteri uji yang digunakan. Volume suspensi bakteri yang digunakan pada setiap tabung dalam pengujian ini adalah $0,1 \mathrm{~mL}$ yang menurut skala McFarland 0,5 setara dengan 0,15 x 108 atau $15 \times 10_{6}$ CFU.
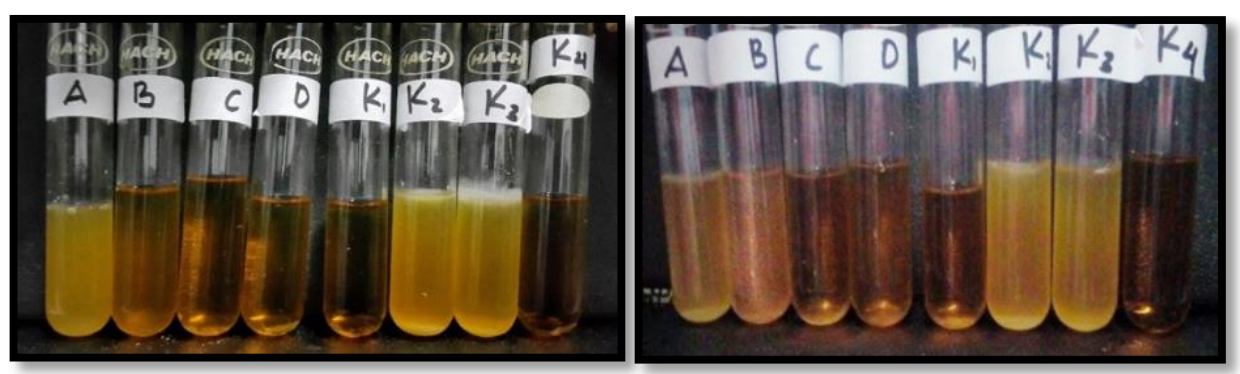

Gambar 1. Penentuan KHM ekstrak terhadap (kiri) S. aureus dan (kanan) E. coli

Hasil pengujian menunjukkan KHM ekstrak terhadap bakteri $S$. aureus adalah $2 \%$ karena pada konsentrasi tersebut tabung tampak jernih artinya tidak terjadi pertumbuhan bakteri. KHM ekstrak terhadap bakteri E. coli adalah 4\%. KHM menunjukkan kombinasi ekstrak bersifat bakteriostatik atau menghambat pertumbuhan bakteri uji. 
Perbedaan KHM disebabkan oleh perbedaan struktur dan komponen penyusun dinding sel kedua bakteri tersebut. Struktur dinding sel E. coli (Gram negatif) lebih kompleks dibandingkan S. aureus (Gram positif). Dinding sel bakteri Gram positif terdiri atas lapisan tunggal peptidoglikan, asam teikoat, dan sedikit lipid. Sedangkan dinding sel bakteri Gram negatif terdiri dari lapisan ganda peptidoglikan, lipoprotein selaput luar, dan lipopolisakarida yang merupakan lipid kompleks.

Penentuan KBM menggunakan metode dilusi padat karena pertumbuhan bakteri tampak lebih jelas dibandingkan pada media cair sehingga pengamatan KBM dapat lebih baik. Hasil yang diperoleh dapat dilihat pada Gambar 2.
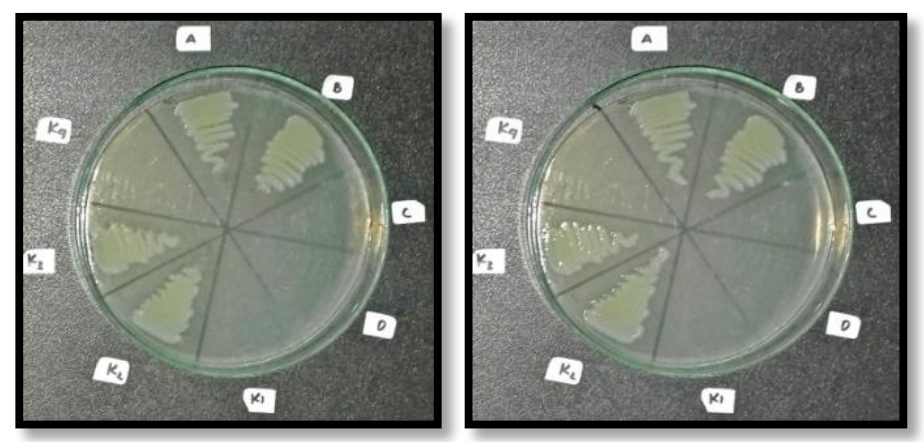

Gambar 2. Penentuan KBM ekstrak terhadap (kiri) S. aureus dan (kanan) E. coli

Hasil pengujian menunjukkan KBM ekstrak terhadap bakteri $S$. aureus dan E. coli adalah $4 \%$ karena pada konsentrasi tersebut tidak nampak pertumbuhan bakteri pada media. KBM menunjukkan kombinasi ekstrak bersifat bakterisidal. Kombinasi ekstrak dapat menjadi alternatif bahan aktif formula hand sanitizer. Mekanisme antibakteri ekstrak disebabkan oleh aktivitas metabolit sekunder dalam ekstrak yaitu alkaloid, flavonoid, terpenoid, dan steroid (Mardiyah dkk., 2014; Andriani dkk., 2015).

\section{Formulasi hand sanitizer}

Konsentrasi kombinasi ekstrak yang ditambahkan ke dalam formula gel hand sanitizer adalah $4 \%$. Metode yang digunakan adalah dispersi mekanik yaitu mendispersikan semua bahan ke dalam pelarut dan mengaduknya hingga diperoleh massa gel yang homogen.

Karbopol digunakan sebagai basis gel karena ketika didispersikan dalam air akan membentuk gel yang jernih dengan penambahan alkali. Karbopol aman digunakan dalam berbagai sediaan kosmetik, toksisitasnya rendah, dan tidak mengiritasi kulit (Rowe dkk., 2009). Konsentrasi karbopol yang digunakan adalah $0,5 \%$ agar diperoleh massa yang cenderung encer karena hand sanitizer harus melepaskan zat aktif dengan cepat. Karbopol didispersikan ke dalam air membentuk dispersi asam yang keruh, kemudian ditambahkan trietanolamin (alkali) maka konsistensi gel akan meningkat dan menjadi bening.

Metil paraben $0,2 \%$ digunakan sebagai pengawet karena gel mengandung banyak air sehingga mendukung tumbuhnya mikroba terutama kapang. Pengawet akan menjaga stabilitas mikrobologi sediaan. Metil paraben merupakan antimikroba spektrum luas dan sangat efektif terhadap kapang (Rowe dkk., 2009).

Propilen glikol $15 \%$ digunakan sebagai humektan untuk menjaga stabilitas sediaan gel dengan cara mencegah kehilangan air. Humektan juga berfungsi menjaga kelembaban kulit karena kandungan alkohol dalam sediaan dapat merenggangkan stuktur lipid kulit sehingga air menguap. Propilen glikol dapat meningkatkan kerja metil paraben sebagai pengawet dan meningkatkan laju difusi zat aktif sehingga cepat berefek. (Rowe dkk., 2009). 


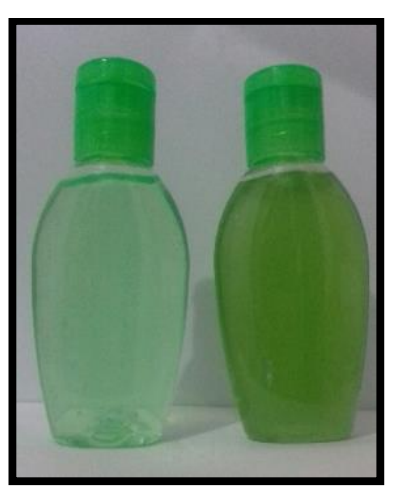

Gambar 3. Sediaan gel (kiri) tanpa ekstrak; (kanan) dengan ekstrak

Etanol 15\% ditambahkan untuk membantu penguapan air dalam sediaan sehingga cepat kering ketika digunakan dan memberikan sensasi dingin. Pewangi green tea ditambahkan untuk menutupi bau sediaan yang kurang baik. Pewarna fast green ditambahkan untuk memperbaiki estetika sediaan.

\section{Karakterisasi sediaan gel hand sanitizer}

Sediaan yang diperoleh berwarna hijau tua dan tampak bening. Nilai $\mathrm{pH}$ sediaan adalah 5,7 yang sesuai dengan syarat pH kulit yaitu 4,5-6,5 (Wilkinson dan Noore, 1982). Nilai pH sediaan cenderung asam karena ekstrak mengandung flavonoid yang bersifat asam.

\section{Uji aktivitas antibakteri sediaan gel hand sanitizer}

Pengujian aktivitas antibakteri sediaan bertujuan memastikan sediaan yang mengandung ekstrak memiliki efek bakterisidal. Kontrol negatif berupa sediaan tanpa ekstrak bertujuan mengetahui apakah basis yang digunakan juga memiliki aktivitas antibakteri atau tidak. Kontrol positif berupa sediaan merek $Y$ (triklosan 1\%) bertujuan membandingkan efek bakterisidal sediaan uji dengan sediaan yang beredar di masyarakat.
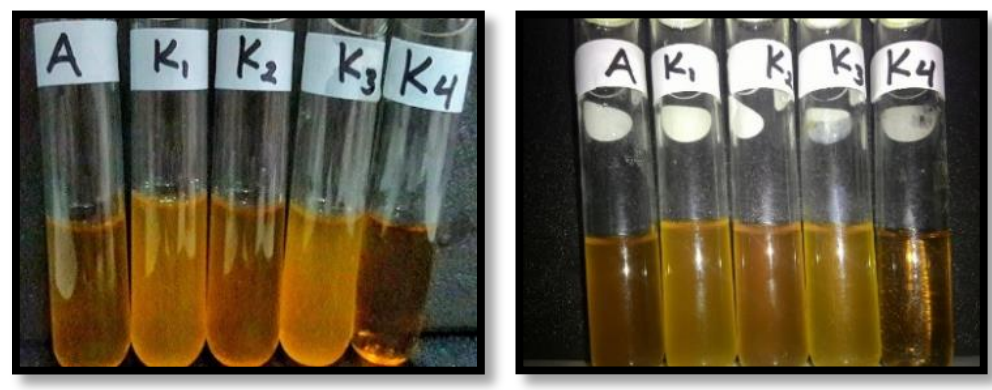

Gambar 4. Penentuan KHM sediaan terhadap (kiri) S. aureus dan (kanan) E. coli
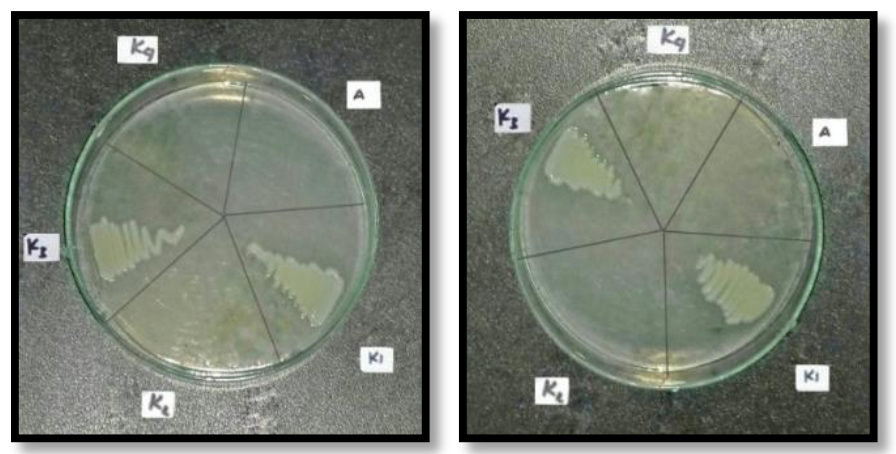

Gambar 5. Aktivitas antibakteri sediaan terhadap bakteri (kiri) S. aureus; (kanan) E. coli

Hasil pengujian menunjukkan sediaan uji yang mengandung kombinasi ekstrak $4 \%$ memiliki aktivitas bakterisidal. Tabung tampak jernih artinya tidak terjadi pertumbuhan bakteri dan tidak ada pertumbuhan bakteri pada media agar di cawan. Kontrol positif juga tidak menunjukkan adanya pertumbuhan bakteri. Maka sediaan uji yang mengandung kombinasi ekstrak memiliki aktivitas antibakteri yang sama dengan kontrol positif yang mengandung triklosan $1 \%$ yaitu bersifat bakterisidal. Kombinasi ekstrak mengandung alkaloid, steroid, terpenoid, sapononin, dan tanin yang terbukti memilik aktivitas antibakteri.

Alkaloid memiliki gugus basa yang apabila berkontak dengan bakteri akan bereaksi dengan asam 
amino penyusun dinding sel bakteri dan DNA bakteri yang merupakan penyusun utama inti sel. Perubahan susunan asam amino mempengaruhi keseimbangan genetik DNA sehingga terjadi kerusakan DNA yang mendorong terjadinya lisis pada inti sel. Kerusakan sel mengakibatkan bakteri tidak mampu melakukan metabolism. (Siregar dkk., 2012).

Flavonoid menghambat sintesis asam nukleat yang peran dalam proses interkelasi atau ikatan hidrogen dengan menumpuk basa pada asam nukleat yang menghambat pembentukan DNA dan RNA. Hal ini menyebabkan kerusakan permeabilitas dinding sel bakteri dan lisosom. Flavonoid juga menghambat fungsi membran sel yaitu membentuk senyawa kompleks dengan protein ekstravaskuler sehingga merusak membran sel dan diikuti dengan keluarnya senyawa intraselular. Flavonoid mengganggu permeabilitas membran sel dan menghambat ikatan enzim ATP-ase dan fosfolipase. Selain itu, flavonoid menghambat metabolisme energi dengan menghambat penggunaan oksigen oleh bakteri. Flavonoid menghambat sitokrom C reduktase sehingga proses metabolisme dan biosintesis makromolekul terhambat. (Cushnie dan Andrew, 2005).

Steroid merusak membran sel bakteri dengan meningkatkan permeabilitas sel, sehingga terjadi kebocoran sel yang diikuti keluarnya material interaseluler (Alamsyah dkk., 2014). Steroid berinteraksi dengan membran fosfolipid sel yang bersifat permeabel terhadap senyawa lipofilik. Akibatnya integritas membran menurun serta morfologi membran sel berubah yang menyebabkan sel rapuh dan lisis (Bontjura dkk., 2015).

Terpenoid membentuk ikatan polimer yang kuat dengan porin (protein transmembran) sehingga porin tersebut rusak. Akibatnya sel bakteri kekurangan nutrisi sehingga pertumbuhannya terhambat. Terpenoid mudah larut dalam lipid akibatnya senyawa terpenoid lebih mudah menembus dinding sel bakteri.

Saponin menyebabkan kebocoran protein dan enzim di dalam sel. Saponin berdifusi melalui membran sitoplasma sehingga mengurangi stabilitas membran sel. Akibatnya sitoplasma bocor keluar dari sel dan terjadi kematian sel. Bahan antimikroba yang mengganggu membran sitoplasma bersifat bakterisida (Taufiq dkk., 2015).

Tanin menghambat enzim reverse transkriptase dan DNA topoisomerase sehingga sel bakteri tidak dapat terbentuk. Tanin dapat menginaktifkan enzim dan menggangu transport protein pada lapisan dalam sel. Tanin juga mempunyai target pada polipeptida dinding sel sehingga pembentukan dinding sel kurang sempurna. Akibatnya sel bakteri menjadi lisis karena tekanan osmotik dan fisik sehingga sel bakteri akan mati (Ngajowa, dkk., 2013).

\section{KESIMPULAN}

1. KHM kombinasi ekstrak rumput laut $E$. spinosum dan E. cottonii terhadap bakteri $S$. aureus adalah $2 \%$ dan terhadap bakteri $E$. coli adalah $4 \%$. KBM kombinasi ekstrak terhadap bakteri $S$. aureus dan E.coli adalah $4 \%$.

2. Kombinasi ekstrak rumput laut $E$. spinosum dan $E$. cottonii dapat diformulasi menjadi sediaan gel hand sanitizer yang memenuhi karakterisktik estetika dan $\mathrm{pH}$ kulit

3. Sediaan gel hand sanitizer kombinasi ekstrak rumput laut E. spinosum dan E. cottonii memiliki aktivitas bakterisidal.

\section{DAFTAR PUSTAKA}

Alamsyah, H.K.,, Ita W., dan Agus S. 2014. Aktivitas antibakteri ekstrak rumput laut Sargassum cinereum (J.G. Agardh) dari perairan Pulau Panjang Jepara terhadap bakteri Escherichia coli dan Staphylococcus epidermidis. Journal of Marine Research 3: 69-78.

Al Haj, N., Nurmas, I. M., Mariana, N. S. 2009. Antibacterial activity in marine algae Eucheuma denticulatum against Staphylococcus aureus and Streptococcus pyogenes. Research Journal of Biological Science 4: 519-524.

Andriani, Z., A. Ghanaim F., Ahmad H. 2015 Antibacterial activity of the red Algae Eucheuma cottonii extract from Tanjung Coast, Sumenep Madura. Alchemy: Journal of Chemistry 4: 93-100. 
Arsal. 2014. Potensi perikanan budidaya di Sulawesi Tenggara.

http://arsalgudangilmu.blogspot.co.id/ 2014/05/potensiperikanan-budidaya-di-sulawesi.html [2 April 2016].

Cushnie, 2005, dalam Taufiq, S., Umi Y., dan Siti H., 2015, Uji aktivitas antibakteri ekstrak etanol biji buah pepaya (Carica papaya) terhadap Escherichia coli dan Salmonella Thypii. Prosiding Penelitian Spesia Unisba. 654-661.

Hasriani, Muhammad, A., Umrah U. 2013 Deteksi bakteri Coliform dan Escherichia coli pada depot air minum isi ulang di Kota Pasangkayu Kabupaten Mamuju Utara Sulawesi Barat. Biocelebes. 7:40-48.

Kristiyana, R., 2013, Optimasi penambahan ekstrak etanol daun kemangi sebagai pengganti triclosan dalam menghambat Staphylococcus aureus dan Eschericia coli pada produk sabun cuci tangan cair [Skripsi]. Bogor: Universitas Pakuan.

Mardiyah, U., A. Ghanaim, F., Begum, F., Suci, M. 2014. Ekstraksi, uji aktivitas antioksidan, dan identifikasi golongan senyawa aktif alga merah Eucheuma Spinosum dari Perairan Banyuwangi. Alchemy 3: 39-46.

Ngajowa, M., Jemmy A., Vanda S.K. 2013. Pengaruh antibakteri ekstrak kulit batang matoa (Pometia pinnata) terhadap bakteri Staphylococcus aureus secara in vitro, Jurnal MIPA Unsrat online 2: 128-132.

Paju, N., Pulina, V.Y.Y., Novel, K. 2013. Uji efektivitas salep ekstrak daun binahong (Anredera cordifolia (Ten.) Steenis) pada kelinci (Oryrolagus cuniculuc) yang terinfeksi bakteri Staphylococcus aureus, Pharmacon: Jurnal IImiah Farmasi 2: 1-61.

Rowe, R.C., Sheskey, P.J. dan Quinn, M.E. 2009. Handbook of pharmaceutical excipient, Sixth edition, Pharmaceutical Press and American Pharmacists Association, USA.

Sari, R. dan Dewi I. 2006. Studi efektivitas sediaan gel antiseptik tangan ekstrak daun sirih (Piper betle Linn.). Majalah Farmasi Indonesia 17: 163-169.

Sartika, R., Melki, Anna, I. S. P. 2013. Aktivitas antibakteri ekstrak rumput laut Eucheuma cottoni terhadap bakteri Escherichia coli, Staphylococcus aureus, Vibrio cholera dan Salmonella typhosa, Maspari Journal 5: 98103.
Setyoningrum, E.N.M. 2010.Optimasi formula sabun transparan dengan fase minyak virgin coconut oil dan surfaktan cocamidopropyl betaine: aplikasi desain factorial [Skripsi]. Yogyakarta: Universitas sanata Dharma.

Shu, M. 2013. Formulasi sediaan gel hand sanitizer dengan bahan aktif triklosan 0,5 dan $1 \%$ Calyptra: Jurnal IImiah Mahasiswa Universitas Surabaya 2: 1-14.

Siregar, A.F., Agus, S., Delianis, P. 2012. Potensi antibakteri ekstrak rumput laut terhadap bakteri penyakit kulit Pseudomonas aeruginosa, Staphylococcus epidermidis, dan Micrococcus luteus. Journal of Marin Research 1: 152-160.

Suparmi dan Achmad S. 2009. Mengenal potensi rumput laut : kajian pemanfaatan sumber daya rumput laut dari aspek industri dan kesehatan [Tesis]. Semarang: Universitas Diponegoro.

WHO. 2012. The Top 10 Causes of Death, http://www.who.int/mediacentre/factsheets/fs 310/en/ [28 Maret 2016].

Wilkinson, J. B. dan Noore, R. J. 1982. Harry's Cosmeticology. Seventh Edition. Chemical Publishing. New York. 